\title{
Behavioral and Brain Functions at 15
}

\author{
Wim E. Crusio*
}

Fifteen years ago, on April 22, 2005, the first articles published by the new journal Behavioral and Brain Functions $(B B F)$ were made available online [1]. The journal was the fruit of the enthusiastic efforts of Terje Sagvolden, who would be editor-in-chief until his untimely death in 2011 [2]. To the best of my knowledge, $B B F$ was the first behavioral neuroscience journal that was online-only and open-access (OA). While this may seem to be quite out-of-the-ordinary nowadays, 15 years ago this was an important innovation. Many journals were still paperonly and just a short time before it had become clear that non-paper, "electronic" journals were eligible to be included in MEDLINE/PubMed or the Science Citation Index, or could obtain an impact factor. And although more general online-only OA journals had been established a few years earlier, it was not at all clear whether enough authors would be willing to forego paper and submit to the fledgling journal.

However, Terje's instinct that the time was ripe for an OA journal in the field of behavioral neuroscience proved to be correct and, from the start, the journal received many diverse first rate submissions. By now, 15 years later, the journal has established itself as a well-respected voice in the field, publishing a variety of high-quality articles that are regularly cited in other journals, as shown by its solid current impact factor of 2.125.

From the beginning, the journal published research on a diversity of organisms and this has continued to the present day. Indeed, recent published articles have covered research on fruit flies [3, 4], zebrafish [5], the obligatory rodents [e.g., 6, 7], and humans [8, 9]. Also, many different techniques are used in the articles that we publish, a consequence of the interdisciplinary and

*Correspondence: wim.crusio@u-bordeaux.fr

University of Bordeaux and CNRS, Pessac, France multidisciplinary nature of our field, which draws from psychology, psychiatry, ethology, neuroscience, genetics, developmental biology, and more. As the journal's aims state, we publish research providing insight into the neurobiological mechanisms underlying behavior and brain function, or dysfunction, excluding only studies that are purely clinical.

Over the years, the field has experienced significant growth, as the notion that the most important aspect of brain science is how the brain's output gets translated into behavior gained more and more traction. To paraphrase Theodosius Dobzhansky: Nothing in neuroscience makes sense except in the light of behavior. As a result, more and more neuroscience studies nowadays include at least some behavior.

While Behavioral and Brain Functions covers the whole field of behavioral neuroscience, we are especially interested in covering work that addresses some of the key issues that the field is facing. Two of the most pressing issues are the validation of behavioral concepts [10] and the (related) replicability crisis [11]. Some of the failures to replicate behavioral results may be due to laboratoryspecific conditions. For example, Crabbe and colleagues showed that even rigorously standardized tests sometimes give widely varying results in different laboratories [12]. (It should be stressed here that they also showed that most tests were eminently replicable).

Other failures to replicate, however, lay on a whole different level. From the results of behavioral tests, both in animals and in humans, we infer behavioral concepts such as spatial learning, anxiety, behavioral despair, etc. However, often enough tests that purportedly tap into the same behavioral construct do not correlate with each other [e.g., 13], indicating that perhaps our inferences are missing something. More research on what exactly our behavioral tests are measuring is urgently needed and Behavioral and Brain Functions hopes to play a role

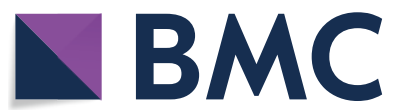

(c) The Author(s) 2020. This article is licensed under a Creative Commons Attribution 4.0 International License, which permits use, sharing, adaptation, distribution and reproduction in any medium or format, as long as you give appropriate credit to the original author(s) and the source, provide a link to the Creative Commons licence, and indicate if changes were made. The images or other third party material in this article are included in the article's Creative Commons licence, unless indicated otherwise in a credit line to the material. If material is not included in the article's Creative Commons licence and your intended use is not permitted by statutory regulation or exceeds the permitted use, you will need to obtain permission directly from the copyright holder. To view a copy of this licence, visit http://creativeco mmons.org/licenses/by/4.0/. The Creative Commons Public Domain Dedication waiver (http://creativecommons.org/publicdomain/ zero/1.0/) applies to the data made available in this article, unless otherwise stated in a credit line to the data. 
in disseminating such work, be it in the form of research articles or reviews.

Finally, at the occasion of our 15th anniversary, I would like to express my sincere gratitude to all those who have worked tirelessly to get the journal where it currently is: my predecessors as editors-in-chief, those who have served as associate editors, and the members of the editorial board. Many thanks are also due to our authors for submitting their work to us for consideration for publication, but above all I want to recognize our unheralded reviewers, who selflessly donate their time, effort, and expertise to maintain the quality of our journal.

While celebrating the successful past 15 years, we look forward with anticipation to the future and further growth of our journal!

Published online: 23 October 2020

\section{References}

1. Sagvolden T. Behavioral and brain functions. A new journal. Behav Brain Funct. 2005;1:1.

2. Sergeant J, Aase H, Faraone SV, Johansen E, Kalaria R, Meyer A, Russell V, Sadile A, Sonuga-Barke E, Tannock R. In memoriam Terje Sagvolden. Behav Brain Funct. 2011;7:5.

3. Chauhan $\mathrm{V}$, Chauhan A. Traumatic injury in female Drosophila melanogaster affects the development and induces behavioral abnormalities in the offspring. Behav Brain Funct. 2019;15:11.
4. Engel GL, Taber K, Vinton E, Crocker AJ. Studying alcohol use disorder using Drosophila melanogaster in the era of 'Big Data'. Behav Brain Funct. 2019;15:7.

5. Zhang S, Liu X, Sun M, Zhang Q, Li T, Li X, Xu J, Zhao X, Chen D, Feng $X$. Reversal of reserpine-induced depression and cognitive disorder in zebrafish by sertraline and Traditional Chinese Medicine (TCM). Behav Brain Funct. 2018;14:13.

6. Malikovic J, Feyissa DD, Kalaba P, Marouf BS, Hoger H, Hartmann MF, Wudy SA, Schuler G, Lubec G, Aradska J, et al. Age and cognitive status dependent differences in blood steroid and thyroid hormone concentrations in intact male rats. Behav Brain Funct. 2019;15:10.

7. Lan A, Stein D, Portillo M, Toiber D, Kofman O. Impaired innate and conditioned social behavior in adult C57Bl6/J mice prenatally exposed to chlorpyrifos. Behav Brain Funct. 2019;15:2.

8. Hayakawa S, Marian V. Consequences of multilingualism for neural architecture. Behav Brain Funct. 2019;15:6.

9. Mock J, Huber S, Bloechle J, Dietrich JF, Bahnmueller J, Rennig J, Klein E, Moeller K. Magnitude processing of symbolic and non-symbolic proportions: an fMRI study. Behav Brain Funct. 2018;14:9.

10. Crusio WE. Key issues in contemporary behavioral genetics. Curr Opin Behav Sci. 2015;2:89-95.

11. Kafkafi N, Agassi J, Chesler EJ, Crabbe JC, Crusio WE, Eilam D, Gerlai R, Golani I, Gomez-Marin A, Heller R, et al. Reproducibility and replicability of rodent phenotyping in preclinical studies. Neurosci Biobehav Rev. 2018;87:218-32.

12. Crabbe JC, Wahlsten D, Dudek BC. Genetics of mouse behavior: interactions with laboratory environment. Science. 1999;284(5420):1670-2.

13. Mineur YS, Belzung C, Crusio WE. Effects of unpredictable chronic mild stress on anxiety and depression-like behavior in mice. Behav Brain Res. 2006; 175:43-50.

\section{Publisher's Note}

Springer Nature remains neutral with regard to jurisdictional claims in published maps and institutional affiliations.
Ready to submit your research? Choose BMC and benefit from:

- fast, convenient online submission

- thorough peer review by experienced researchers in your field

- rapid publication on acceptance

- support for research data, including large and complex data types

- gold Open Access which fosters wider collaboration and increased citations

- maximum visibility for your research: over $100 \mathrm{M}$ website views per year

At BMC, research is always in progress.

Learn more biomedcentral.com/submissions 